\title{
The figure of the impostor to the throne in Russian political culture: Between sacralization and mimesis
}

\author{
Ilya Kalinin \\ Department of Liberal Arts and Sciences \\ St. Petersburg State University \\ 58-60 Galernaya St., St. Petersburg, 190000 \\ Russian Federation \\ e-mail: st006423@spbu.ru
National Research University Higher School of Economics
16 Soyuza Pechatnikov St., St. Petersburg, 190008,
Russian Federation
e-mail: ikalinin@hse.ru

\begin{abstract}
Proceeding from materials relating to the "Time of Troubles", this article examines the phenomenon of imposture (samozvanchestvo) as one of the symbols of Russian political history from the early 17 th to the mid-19th century. The duration of the "impostor epidemic" coincides exactly with that of serfdom, and imposture itself can be described as a social reaction to a form of authority founded on total personal dependence. The article aims to develop further Boris Uspenskij's argument that reveals in sacralization of the Tsar's power in medieval Russia the main reason of imposture. René Girard's conception of mimetic desire serves as the theoretical perspective for such a development.
\end{abstract}

Keywords: imposture; autocracy; power; mimetic desire; Time of Troubles; Russian politics; Boris Uspenskij; René Girard

\section{Autocracy: between sacralization and slavery}

Historically speaking, imposture (samozvanchestvo) was one of the most widespread forms of popular rebellion in Russia, arising from the beginning of the 17th century with "the light hand of the first False Dmitrij", and transforming into "a chronic disease" that constantly plagued the Russian state until 1861 (Klyuchevskij 1988: 
26). Emerging on the Russian political arena with the appearance of the first False Dmitrij and culminating with the last impostor, the False Konstantin, imposture was a regularly reproduced historical subject that played a crucial part in the history of Russian serfdom. The link between imposture and serfdom is not under much dispute; it is clear that the two hundred and fifty year old chronological unity between the slavery of millions and the rise of the impostor challenge is no coincidence. One question that is worthy of examination is what mechanisms linked the intensification of serfdom, on the one hand, with the increasing prevalence of impostors, on the other (Klyuchevskij 1988: 51; Skrynnikov 1981: 151-181; 1988: 45-51). Imposture is largely presented in historiography as a popular reaction to serfdom, "a people's cover of a rebellion" (Panchenko 1996: 25), a political manifestation of mass discontent with the established social, economic and legal order.

In addition, one of the key political features of imposture was its use as a political tactic to exploit the rebellious energy of the enslaved masses. This tactic could be deployed to utilize the power of the supreme authority, which was presented as the "true", "good" or "liberator" Tsar, in a common struggle against landowners. It was popular belief that the "good Tsar" (dobryj tsar') would be on the side of the slaves rebelling against the "bad lords". It was in this way, in the popular consciousness at least, that the figure of the Tsar was elevated to a higher position beyond the established socio-economic order. The peasants' serfdom was not seen as something blessed by the Tsarist authorities; on the contrary, the fact that all the subjects of the Moscow kingdom were slaves under the full power of the Tsar, turned common serfdom into a specific form of equality. This was set in direct opposition to a private form of lawlessness, that of serfdom.

In his work on Russian folk legends from the 17th to the 19th centuries, Kirill Chistov (2013[1967]) introduced another important mechanism linking the relationship between the social and legal realities of the personal tethering of peasants to their owners and the social and political realities of imposture. He sees this link in the construction of a structurally stable and thematically connected folklore narrative, which he termed the legend of the "returning liberator Tsars (tsareviches)" (Chistov 2013[1967]: 49-275). According to this interpretative scheme, impostors do not come into being as a result of a direct political crisis connected to dynastic inheritance problems, nor are they due to the personal adventurism of certain historical figures. Instead, they arise in the specific expectations of the masses, who textually construct their ideas into a kind of folk ideology (Chistov 2013 [1967]: 50-51). The success of imposture and its unprecedentedly wide dissemination in Russian political culture can thus be explained by the fact that the impostor historically transformed already existing and textually crystallized imaginations into reality, becoming a material continuation and embodiment of folk legend. 
One of the most convincing approaches to imposture can be found in the work of Boris Uspenskij (1994c[1982]), who developed the conception that this phenomenon is less about a mass desire for liberation, but more about the ambitions of both secular and ecclesiastical elites to achieve the sacralization of the very nature of royal power and bolster the figure of the Tsar. ${ }^{1}$ As Uspenskij quite rightly points out, impostors appear in Russia only after the establishment of royal power and authority (modelled on the Byzantine version), which brought with it ideas of divine origin and the practice of sacralization rituals (Uspenskij 1994c[1982]: 76). The question of charisma, to which we shall return later in this article, is the key here. Uspenskij puts special emphasis on the point that "the first impostor appeared in Russia shortly after a proper procedure was added to the Tsar's initiation ceremony: alongside coronation the practice of anointing with chrism (or myrrh) was added, which gave the Tsar a special kind of special charismatic status: with anointment, the king became similar to Christ" (Uspenskij 1994c[1982]: 76). ${ }^{2}$

This conception is based on a semiotic version of the history of culture that takes a model of history emphasizing the communication between society and those in power (see Uspenskij 1994a[1976]: 50-60, 1994b[1989]: 9-50). According to this interpretation of imposture, a distinction is made between the causes behind the appearance of impostors and the reasons explaining why the masses decided to support them. Uspenskij suggests that utopian legends and the hopes engrained within them for a "good Tsar" who would free the peasants from the prison of serfdom, only explain the "public reaction to [...] the appearance" of impostors, but "the psychology of the impostor himself is based on religious ideas about the sacred nature of royal power" (Uspenskij 1994c: 73-76).

This distinction between two historical lenses, positioned at different poles of the communicative model (in this case, the royal power and the people as the carrier of specific ideas about Tsarist authority), was offered by Uspenskij as the basis for a semiotic description of the historical process. For example, in his article "Historia sub specie semioticae" (1976), Uspenskij proposed an innovative description of Peter's reforms, setting up two opposing perspectives of their perception and depiction: from the addressee's point of view (supreme authority and Peter I) and from the addresser's one (Russian people) (Uspenskij 1994a[1976]: 50-60). In this study of Peter's reforms, the point of view of the "audience" (the people) was given priority in terms of its historical position. In the eyes of "audience", the modernizing and westernizing

1 For more on the sacral charisma of autocratic power in Russia and its Byzantine roots, see Uspenskij 1994d[1987]: 110-218 and 1998.

2 In a work concerning the charisma of tsarist power in Russia, Uspenskij reinforced this point, noting that if in Byzantium and in the West the monarch during anointment was likened to the kings of Israel, in Russia he was likened to Christ; see Uspenskij 1998: 20-21. 
policies of Peter were not a cultural or historical novelty; people perceived it as a perversion or an overturning of the tradition, a trend that was linked to the coming of the Antichrist. ${ }^{3}$

It is symptomatic that in his work on imposture Uspenskij, rejecting a priority position of the society's point of view ("public reaction to the appearance of impostors"), but focusing on the position of the self-proclaimed impostor to the royal throne ("psychology of the impostor" as it were the position of power), comes to the same conclusions as he did when examining Peter's reforms, which he reconstructed from the point of view of society: "As a specific type of behaviour, imposture entirely fits with a situation that is traditional for Russia, suggesting that, alongside correct normative behaviour, there is also anti-behaviour in one form or another [...]. In other words, imposture satisfies the tradition of anti-behaviour in Russia" (Uspenskij 1994c[1982]: 89). Peter's reforms, thus, are a mirror image of the Time of Troubles; Peter's modernization efforts correspond symmetrically with the imposture's perversion of the autocratic power's sacred nature. History appears as tradition turned inside out, and the movement of history itself is defined as the choice between "correct, normative behaviour" (when the king is a king and the slave is a slave) and "anti-behaviour", which, roughly speaking, falls into two types: one where the Tsar starts behaving like a slave (the case of Peter I) or one where the slave begins to behave like a Tsar (the case of False Dmitrij I). ${ }^{4}$

\section{Autocracy and a crisis of differences}

However, this analytical lens, which reduces the history of Russia to a series of deviations from and returns to certain norms such as harmony between status and role, the sacral idea and its earthly embodiment, social order and individual behaviour, can be developed further and problematized. The tradition of imposture can also be viewed as one of the central plotlines in Russian history, one that unfolds at the intersection of three socio-political and socio-cultural phenomena. If we allow a certain degree of "ideal-type" schematics, three lines that interweave on the scene of imposture can be discerned as follows. Firstly, we have slavery: the staying of people in personal or state ownership. Secondly, we have autocracy, which entails conceptualizing the state as an ancestral estate personally owned by the ruler. Finally,

3 See my analysis (Kalinin 2009) of this and other works of Uspenskij, which reveals a number of ideological presuppositions determining the semiotic description of culture, characteristic of the Tartu-Moscow School of Semiotics.

4 See also a study devoted specifically to the tradition of anti-behaviour in Russia: Uspenskij $1994 \mathrm{e}[1985]$. 
we have the social contract, which shifts from the sacral legitimization of the Tsar as the supreme authority, the monarch as a figure representing God, to a more abstract, legal and rational notion of a figure representing the estate and the people in general. This is also a transition from slavery to more formally established written rules.

The inner dialectical nature of imposture, one that contained the slave and the aristocrat, formal legitimacy and its denial, the subject and his struggle for recognition, the thesis of the autocrat and the antithesis of the slave, is well suited to an analysis based on the framework of Hegelian phenomenology. This is particularly the case as regards the politicized reading of Hegel proposed by Alexandre Kojève (1980[1947], 2014[1942]). This productive discussion, however, is beyond the scope of this article. For us a struggle that lays at the heart of imposture - between individual power and slavery, divine order and personal charisma, nature and pretention, the individual and the universal, as well as between political power and society - is so important because it allows to remove these dichotomies. The history of imposture permits us to see slavery not as an external effect, but as an internal form of autocracy itself, and to describe the usurpation of power not as an exception to the rules, but as a generic feature of it. ${ }^{5}$

According to this perspective, imposture no longer appears to be "a people's cover of a rebellion"; rather, a rebellion appears to be a people's cover of power, mirroring the multiplication of violence, intercepting the state's monopoly of the latter and redistributing power in its most radical manifestation. Imposture and autocracy do not oppose each other as a false and a true power; this opposition is only a part of the self-legitimate language of the winner in this contest. Instead, imposture reveals the emptiness of the grounds on which "true" power rests. It is in this sense that imposture is not so much an anti-behaviour that opposes the norm (as Uspenskij considers it to be), but is, rather, behaviour that reveals the emptiness and conventionality of the norm itself. This is behaviour that indicates the illegality of the law, reveals the human arbitrariness of the sacred aura that extends to the figure of the Tsar, even after the magical miracle-working in the Middle Ages (Bloch 1998[1924]) and the liturgical sacredness of monarchical power (Kantorowicz 1994[1957]) had already receded into the past.

In other words, imposture reveals the self-proclaimed (or auto-proclaimed) nature of autocratic power itself in the form it acquired since the start of the early modern era. The internal duality of the figure of the impostor opens up the possibility of removing a number of oppositions - such as political power and society, state and society, autocracy and slavery, the addressee and the addresser (in semiotic terms referring to

5 As many philosophers and political theorists have noted, starting from the Baroque era the monarch was defined as acting as a replacement for God, or as a usurper. For more on this, see the chapter "The place of God: The sovereign as usurper" in Yampol'skij 2004: 153-183. 
the description of culture) - because the figure of the impostor combines both of these terms, being an attempt of those without power to present themselves as possessing it. By staking his own life in the struggle for recognition, the impostor embodies the relativity of both positions, which persists until his attempt to question the existing divisions finally reaches its conclusion.

Objectifying the reducibility in the borders between 'being' and 'appearing'; between the slave and the master (Hegel), between role and status (Smirnov 2004: 223-240), between the sacral and the profane (Uspenskij), between the body and the text (Chistov), the emergence of an impostor was a symptom of the social crisis caused by the collapse of a cementing cultural order buttressed by a system of differences. Combining psychoanalysis and structural anthropology, finding new theoretical intuitions in the sources of myth, Greek tragedy, the Scripture and modern literature that go beyond structuralism and psychoanalysis, René Girard defined the cultural order "as an ordered system of differences, since it is the presence of differential intervals that allows individuals to find their own 'identity' and to settle down next to one another" (Girard 2005[1972]: 52). When examining mythological and literary images of doubles in the form of twin brothers or hybrid monsters that are assembled of fragmented features of creatures (creatures that had lost the differences between them), Girard saw these as a cultural reflection on the crisis of differences threatening society. Girard could easily have included the figure of the impostor in this list of monstrous hybrid creatures. And he would probably have done so, had he read not only Dostoevskij (Girard 1963), but also Pushkin's Boris Godunov or The Captain's Daughter. The basis for such a step is all the more solid, given that, unlike doubles or twins entering into a fatal battle, in the case of an impostor we are faced not just with a cultural representation that captures the traces of a reflexive reaction to a crisis, but with the crisis itself, a crisis unfolding in the space of history.

The Time of Troubles, which gave birth to the first and one of the biggest waves of imposture, offers an example of such a crisis, which was a result of systemic changes that were initiated by Ivan the Terrible who comprehensively transformed the former social order into an object of monarchic tyranny. The overhaul of this system was meant to demonstrate the total domination of the king over his subjects, who were deprived of any differences with respect to the sovereign and were absolutely similar to him. Confirming this dominance, Ivan the Terrible himself could play a serf-like role, for instance when he signed the humble petition to Simeon Bekbulatovich, the Astrakhan tsarevich, who was falsely put on the Russian throne by Ivan the Terrible, as "Ivanets Vasilev". However, relying on the traditional type of domination, whose domestic justification was rooted in the authority of the dynastic continuity of the family (see Weber 1999[1919]: 398), Ivan IV managed to retain control over the game of differences and overcoming them that he performed. The sameness between dummy 
kings and himself that Ivan IV played with is an example of what Girard (2005[1972]: 264-289) called a "sacrificial substitution". Thus, laws were issued on behalf of Simeon Bekbulatovich that revived the division between the Zemstvo and the oprichnina, which formally made him guilty of the next round of state terror. There was also a more obvious case of sacrificial substitution: "Thus, in 1567 Ivan the Terrible ordered the boyar Ivan Petrovich Fedorov (Chelyadnin) (who was suspected of conspiracy) (...) to be put in royal dress and given a sceptre and other signs of royal dignity and put him on the throne. Then bowing to his feet and paying all the honours worthy of a Tsar, Ivan IV killed the disguised king with his own hand." (Uspenskij 1994c: 84). Replacing himself with the "impostor" tsar, who assumes a kingly appearance and acts simultaneously as the internal antagonist of the Tsar (conspirator) and his external double, allows him to sacrifice the "disguised king" whose figure embodied all ritually necessary relations of sameness and difference. Thus, from the outset, imposture appears as a strategy of autocratic power itself, which generates its double that is to be sacrificed in order to demonstrate the unlimited control of the Tsar over the lives of his subjects.

However, the dynastic crisis that erupted after the death of Ivan the Terrible's son brought to a new level the game of sameness (all subjects are in full power of the Tsar) and differences (it is in the power of the Tsar to redistribute internal boundaries and to bestow honours not according to rank, but at discretion) that had been initiated by the autocratic authorities. Now autocratic power was no longer able to control the progress of this game. Dynastic succession was broken when Boris Godunov, brother of the widow of Fedor Ioannovich, was elected as the Tsar and ascended the throne at the decision of the Zemskij Sobor. In other words, he received power from the representatives of the estates and the boyar elite. His dominance could no longer rest on the symbolic resources of traditional legitimacy, which was built on the immortality of the ancestral political body of the king. ${ }^{6}$

The contemporary and namesake of Ivan the Terrible, the philosopher and member of the French Parliament Jean Bodin, was the first to develop a theory of state sovereignty as "the absolute and perpetual power" (quoted by Schmitt 2005[1922]: 8). He already saw state sovereignty as something that could be detached from the "concrete body" of the monarch, but capable of existing "only in modes with uninterrupted continuity" (Yampol'skij 2004: 624). But it was precisely the election of Boris Godunov to the throne that constituted an interruption of this continuity. According to Yampol'skij, separating the concept of sovereignty from the body of the monarch led to its abstraction, something Bodin avoided thanks to an emphasis on "the forces of continuity" (Yampol'skij 2004: 624), transcending the body of a

6 See the chapter dedicated to the principle of a dynastical succession "The king never dies" in Kantorowicz 1997[1957]: 314-451. 
sovereign with the idea of sovereignty. It is for this reason Bodin could not recognize the legitimacy of a procedure for electing a sovereign, as this would mean a final transition to what Weber would define as a legal or rational type of authority (Weber 1999[1919]).

The legitimacy of Boris Godunov was simultaneously abstract and not uninterrupted: he was first elected and only afterwards anointed with Chrism and crowned to the throne. Thus, the sacred production of his royal charisma was carried out ex post facto, retrospectively consecrating in the name of God what had already been decided by representatives of the people. D. I. Timofeev, the author of "The Chronicles" (Vremennik, 1610s), a history of the Time of Troubles, introduced a special distinction between the former "hereditary" kings, whom he calls "autocratic", and the new "electoral" kings, such as Boris Godunov and Vasilij Shuiskij. The latter two just served as a model for a string of impostors: "The first (Boris) was a teacher to the second, the second to the third, [...] and all that followed were 'unnamed cattle, not kings'; the first usurpers paved the way for regional impostors" (Klyuchevskij 1989: 170).

The Time of Troubles came at the same time as a crisis in the sacredness of power, and as a break in the continuity of dynastic succession, and as a violation of the system of samenesses and differences in which the struggle between the Tsar and the impostor embodied the inner dialectics inherent to the relationship between autocracy and slavery: what had previously been a fundamental difference was now transformed into sameness; yesterday's slave becomes the king. The Time of Troubles represented a disintegration of the socio-cultural order that was similar to what Girard has described in the context of the decomposition of religion: "The institutions lost their vitality; the protective facade of the society giving away; social values are rapidly eroded, and the whole cultural structure appears on the verge of collapse." (Girard 2005: 52). According to Girard's analytical logic, the system of differences that structure a society is able to control violence by concentrating the stress accumulated in society and transferring it to the figure of the victim, which, in accordance with a given society's cultural development, appears first in the form of a person, then in the form of a sacrificial animal and finally as a symbol that substituted the previous forms (Girard 2005: 1-41). In modern society, such a victim is inscribed in the social contract, it is a formal right based on the fact that people reject (sacrifice) natural freedom in order to control violence that, as Hobbes (1965[1651]: 95) writes in Leviathan, is rooted in a constant competition that is the reverse side of original natural equality. In other words, if we follow the logic of Girard, the never-ending prospect of a possible crisis of differences is rooted in human nature.

Sacrifice is a structural element that is simultaneously located outside the system of differences while also ensuring its existence as it establishes the boundary between sameness and difference; the sacrifice should be similar to those whom it replaces 
and, at the same time, be different from ordinary members of the community (Girard 2005: 6-11). Therefore, examples of sacrifices can be found in prisoners of war, slaves, children, the disabled, witches, heretics, jesters and kings. Sacrificial rituals involving kings were described in detail by James G. Frazer in The Golden Bough. ${ }^{7}$ Further studies on the sacral exclusion of the king's figure from the earthly society are offered by Ernst Kantorowicz (1957) and Marc Bloch (1998[1924]), Boris Uspenskij (1998) and Mihail Yampol'skij (2004: 25-286). According to Hobbes and Bodin, the monarch is alone and stands above this order; Schmitt develops this further to argue that kingly authority is not based on norms, but decisions (Schmitt 2005: 12-13, 1635). Therefore, the figure of the king turns out to be a similar sacrificial focus in the game of difference as a slave is.

\section{Autocracy and its mimetic double}

The Time of Troubles provides a paradoxical example of how an officially recognized king was deprived of all his signs of exclusion from society (including both the divine sacral and the natural-dynastic ones) to the point that he became too weak a figure to maintain the cultural order, defining who or what should be sacrificed. What is more, he was also too weak even to act as a person to be sacrificed himself because the sameness of the king and his subjects triumphed over the difference between them. The way out of this impasse was found in imposture, something that would seem to be an even more radicalized form of the structural crisis described above. The impostor emerges as a sacral and charismatic compensation for the symbolically devalued figure of the officially elected king. This is precisely how Klyuchevskij describes the gap between the sacral and profane, patrimonial and individual that is overcome by the figure of the impostor. The impostor is part of the people's hope to return to the previous type of rule, that of established authoritative tradition rather than any rational contract (in Weberian terms). Thus, we arrive at the reason for mass support of Otrep'ev: "...simple minds could not comprehend as the 'true' king neither Boris Godunov nor Vasilij Shuiskij, never mind the Polish king Vladislav: they saw them as usurpers, while the mere spectre of the natural king, even if it was a rascal of unknown origin, soothed dynastic legitimacy concerns and inspired confidence" (Klyuchevskij 1988: 50).

The lack of a "natural" king, meaning one given by God and rooted in dynastic continuity, was solved by the impostor who, unlike the "nationally" elected Tsar, could claim having been divinely selected, as well as dynastic legitimacy. The figure of the "rascal" cemented the gap between the old and the new (legal) types of authority, as the

7 See Frazer 1994[1890], Ch. 24, “The killing of the divine king”. 
latter was seen, from the point of view of "traditional dynastic legitimacy concerns", as a form of usurpation. Through the act of imposture, the former slave gained a second birth, becoming a "true" king in the eyes of the people, unlike the "elected" Tsar, who had had no opportunity for a second sacred birth. This was because his power had already been demystified due to the rationalism inherent to the new social contract. It is due to this that the impostor, who was a slave with pretensions to sacral and dynastic legitimacy in his desire to occupy the throne of the king, became a stronger and more suitable figure to help escape a "sacrificial crisis". René Girard defined a "sacrificial crisis" as a kind of violence that has escalated out of control and continues to grow in strength due to a shattered system of differences and identities that no longer allows the correct type of redemptive sacrifice (Girard 2005: 41-72). In order to offer a way out of this situation, an impostor is born who becomes the focal point of a new socio-cultural assembly, drawing in all the accumulated tensions of society: "Imposture was the most convenient way out of this struggle of irreconcilable interests, which was aggravated by the interruption of the dynastic succession; it mechanically and forcibly united under familiar though counterfeit authority, elements of a society on the verge of disintegration, between which it had become impossible to find an organic, voluntary agreement" (Klyuchevskij 1988: 55).

In other words, the counterfeit nature of self-proclaimed power was a way of returning to the previous "natural" autocratic power, while simultaneously channelling the rebellious energy of the enserfed population into a struggle for the "true" autocracy. The impostor emerged as a spectre of the natural king, a bodily symbol signifying the most fundamental and universally recognized attribute of the medieval sovereign: his inclusion in the ancestral-natural-divine order. Paradoxically, the impostor turned out to be not just the antagonist twin of the autocrat, but the core of his lost sovereign essence which separated from the figure of the ruling monarch during a crisis of his legitimacy. At the moment when the autocrat becomes an "elective king" ("yesterday's slave"), his second body, that of the sacral and political, leaves the sovereign, who now rules under a contract with representatives of the state. This political body finds a new home and an independent life in the figure of the impostor, who relies on a more typical type of legitimacy. Along with this physical literalization of the dual nature of the sovereign, in which we can find the apparent division of his two bodies between two personalities competing for the power, we are also exposed to a scandalous emptiness, which emerges from the original unity of the two bodies in the figure of the monarch. The physical (natural) body of the Moscow Tsar belongs to the "usurper" (Boris Godunov) while his political (sacred) body, which concentrates within itself the idea of dynastic continuity for the Moscow kingdom, belongs to the "rascal". 
The duality of the monarch's figure, which is objectified by the impostor, resembles the dynamics of "mimetic rivalry", which, from the point of view of René Girard, determines the nature of desire: "The subject desires the object because the rival desires it. In desiring an object the rival alerts the subject to the desirability of the object" (Girard 1972: 154-155). The horizon of rivalry, staying behind the emergence and direction of desire, makes the latter an inseparable companion to violence, as the imitative nature of desire predetermines its constant encounter with a competitor taken as its model. The prospect of defeat reinforces this desire, which, in turn, strengthens the mimetic tendency, instilling hope of a victory over the rival, inevitably taking the violence to the next level and, thus, into a spiral: "Mimetism engenders rivalry, and rivalry, in turn, strengthens mimetism" (Girard 1963: 23).

In the end, the mimetism of desire makes the differences between antagonists all less significant and noticeable, and the level of violence is ever higher. The resulting crisis of differences leads to a pandemic multiplication of twins, which reproduces an increasingly fractional system of differences. The action of this particular mechanism can also be observed during the Time of Troubles: even the name given to the period (Time of Troubles, Epoha Smuty, in Russian) seems to emphasize the moment of nondifferentiation, confusing the usual differential signs among themselves. The presence of one self-proclaimed king (Boris Godunov), produces the first division and the first couple of mimetic rivals that coincide in the figure of the "elected" autocrat: one who was born a subject, and the model Other who achieves supreme power. However, this internal split, the unification of opposites in the figure of yesterday's slave who has become king, provokes a further series of increasingly smaller differences that, in turn, claim a sovereign sameness with the person of the monarch and lead to further violence in the struggle to prove this sameness.

The crisis of differences, which may be further enhanced by the coincidentia oppositorum that was characteristic of baroque thinking, could not be resolved by concentrating all the tensions and contradictions of the current situation into the figure of a single impostor. On the contrary, his appearance triggered a chain reaction of imposture, a feverish play of incessant doubling and multiplication of differences, all of which was to be united in the figure of the impostor, thus reproducing the fundamental secret of sovereign power itself: its duality and emptiness. So it was that as many as fifteen characters participated in this Time of Troubles Parade of Impostors, including 'Grishka Otrep'ev, (...) the 'Tushinskij thief', the 'Princes': Peter, IvanAugustus, Clementine, Savelij, Vasilij, Erofej, Gavrila, Martyn and Lavrentij. All of these presented themselves as the children and grandchildren of Ivan IV" (Panchenko 1996: 25). Moreover, after the death of Boris Godunov, the country was swamped with rumours that he was actually still alive, and that, in fact, his double had been buried in his place (Skrynnikov 1988: 232), which was exactly the same tale as the story used with Prince Dmitrij. The death of another elected boyar tsar, Vasilij Shuiskij, again 
reproduced the same pattern: self-proclaimed descendants also emerged to present their claims to the throne (Panchenko 1996: 25).

Describing mimetic rivalry and the violence it produces, Girard discovers a paradigmatic pattern in the rivalry for individual power, in the impermanence that characterizes the fate of the tyrant: "A newcomer can ascend unexpectedly to the very summit of power, only to plummet, while one of his opponents assumes his lost positions. In short, there is always a tyrant and always an oppressed, but the roles alternate", antagonists never take the same position at the same time; they inherit each other's (Girard 1972: 158, 167). However, the nature of the antagonism between the tyrant and the oppressed unfolding on the scene of imposture is that in the internal drama of power they do simultaneously occupy one and the same position, embodying the same claim for the possession of absolute sovereignty. In this case, the king cannot rid himself of self-proclaimed doubles, and the impostor cannot abandon his royal destiny. Thus, it is not only about the impermanence of tyrannical power or the constant fluctuations allowing the king and the oppressed to change places constantly. The case described here suggests that the coexistence of the tyrant and the downtrodden in the figure of the absolute monarch, within which the inner mimetic rivalry between the king and the slave unfolds, emerges to the surface at a certain moment in the form of rivalry between the autocrat and the impostor.

\section{Splitting autocracy}

Tearing apart the polarity behind the figure of the Tsar ascending the throne on the eve of the Time of Troubles, Ivan Timofeev very acutely and accurately defined Godunov as a "Slave-Tsar" (rabotzar') (Russkaya istoricheskaya biblioteka 1891: 330). Godunov's duality was constantly accentuated in describing his character and behaviour. Summarizing these characteristics from the point of view of his contemporaries, Klyuchevskij (1988: 24) wrote: "He was able to cause surprise and gratitude, but instilled confidence in nobody; he was always suspected of duplicity and insidiousness ... the 'Slave-Tsar' seemed to them a mysterious mixture of good and evil, a player". The game of differences and sameness embodied in the figure of the "Slave-Tsar" leads to the emergence of a centaur-like, monstrous, self-proclaimed creature born of the ruins of a medieval political theology that had relied heavily on the notion of the divine nature of the monarch. The "Slave-Tsar" replaces the "GodTsar" in the same way as the "mortal god" of Hobbes's Leviathan, born from the social contract, replaces the divine legitimacy of the medieval sovereign. The impostor just makes visible the disparity between the ancestral and the individual, between the divine (royal) position and the human (slave) descent, between celestial selection and the social contract, between sacralization and the mimetic doubling with which it competes. 
However, even before the impostor, this gap was felt by the autocrat himself, who also felt pursued by his own duality and suspected duplicity among those around him. The general denunciation that he initiated was a means of overcoming his own "SlaveTsar" split: according to his decree, slaves had to report to their masters, receiving part of their property even for a false denunciation (Margeret 1986: 264). This terror plunged society into a cycle of slavish dependence, which, like an infection, was transmitted from slaves to masters and back again, once again removing differences and bringing a socio-cultural crisis closer. An impure conscience gave birth to the phantom of the impostor who would pursue the autocrat. This phantom preceded the real appearance of the impostor: firmly knowing that the youngest son of Ivan IV was dead, Godunov was at times in doubt, "almost deprived of reason and not knowing whether to believe if Dmitrij was alive or dead" (Massa 1937: 82-83). When, however, his own doubts began to find confirmation in the rumours spreading through the country, he ordered intensified repressive measures, thereby once again bringing the approaching crisis closer: "Having heard in the year 1600 the rumour that some consider Dmitrij Ivanovich to be alive, he has since this spent days torturing and tormenting on this matter" (Margeret 1986: 264). The internal fear forced the king to hide in the palace, stop accepting petitions, which the former kings did, and even send out a special prayer for his health, which was to be pronounced during meal times in all houses; he "suspected everybody and was tormented by memories and fears, he showed that he was afraid of everyone, and, in the apt words of one foreigner then living in Moscow, he was like a thief who was afraid of being caught at any minute" (Klyuchevskij 1988: 30). These "apt words" again confirm the duality of 'king' and 'slave, 'king' and 'thief', which coincide in the figure of an elected autocrat, anticipating the appearance of a real impostor ('thief', in Russian 'vor').

However, there was another alternative solution to the crisis of differences caused by the election of "yesterday's slave" to the throne other than upheaval, imposture and the Time of Troubles. This was the consistent and rational recognition of the contractual nature of his power by the newly elected king. Had this happened the first transition to constitutional monarchy would have occurred not in England but in Russia, and not in 1689, but in 1598. Similar preconditions existed for this, and in some ways, they were even more compelling than those facing King William III of Orange (a representative of the former Stuart dynasty and grandson of the executed Charles I), who was elected sovereign by the British Parliament. Unlike William III, who was a representative of the old dynasty, Boris did not belong to the family of Ivan Kalita, so that his power had to rest solely on legal, contractual and "bureaucratic" grounds. And indeed "the boyars (...) with a Tsar elected from their brethren were not content with the simple custom on which their political significance was maintained under the previous dynasty. They expected Boris to provide a more lasting guarantee of this meaning, in other words they wanted restrictions on his authority by a formal 
act" (Klyuchevskij 1988: 27). It was, therefore, the desire of the boyar elite to limit the power of an elected tsar, through the establishment of a formally concluded agreement that would de jure reinforce a new political custom, the validity of which was de facto no longer based on the divine order, but on human institutions. In fact, the Tsarist power of Godunov, even before the actual appearance of the first impostor, raised the curtain to expose the self-styled or self-proclaimed grounds of autocratic power. This was because nothing remained to bridge the gap between the legal reality of the election and the autocratic desire to rule according to the previous ancestral notion of the state as a personal possession of the Tsar upon that his "uninterrupted" and, according to Boden, "unlimited" monarchical power covered. The decision to rule autocratically corresponded to the basic principle of sovereignty that was asserted within the framework of baroque "political theology", and made evident the emptiness of this autocratic decision. It was this emptiness which was filled with characteristic sacraldynastic ideas on the nature of power that became the breeding ground for imposture.

The start of these internal confrontations came right after the election of Boris, who attempted to reproduce formally the previous form of autocratic rule without any substantive reasons for doing so: "Boris should (...) turn the Zemskij Sobor from an occasional official meeting into a permanent people's representation (...). But [he], due to a lack of political consciousness, outwitted himself. When the boyars saw that (...) the new tsar reigned just as autocratically as Ivan the Terrible, they decided to act secretly against him." (Klyuchevskij 1988: 29). Thus, from a political point of view, imposture arises at the intersection of two factors: (1) the inconsistency of new supreme authority with the previous dominant notions shared by the majority of the population; (2) the inability of the new supreme authority to introduce a new type of government that was in interest of the aristocratic elite. In other words, the new Tsarist power preferred to rely on symbolic grounds that it no longer met, and reject those rational forms that it had actually established. These scissors eventually cut the figure of the sovereign into two opposing parts. Firstly, this occurred at the level of an internal crisis of legitimacy, duplicity and suspicion of the duplicity of others, fear and terror. Secondly, this happened at the level of real confrontation between the autocrat and the impostor, which only objectified the already existing, splits within the figure of the autocrat.

From this perspective, imposture is a phenomenon that reflects the internal crisis of the very "autocratic" form of rule, bringing its internal split into material form, which was a conflict between individual arbitrariness and the claim to an ancestral and sacralized right of undivided domination. In the place of the failed transition from the figure of the autocrat to the figure of a monarch bound by the social contract, the first figure splits, revealing the distinction between 'individual' and 'ancestral', 'social' and 'sacral,' 'conventional' and 'unconditional'. However, after the developing mimetic rivalry for power between the autocrat and the impostor, the figure of the autocrat 
again regains its phantom unity. This unity, however, is constantly pursued by the spectre of imposture. This could come in the form of real impostors, or in the form of their phantoms, with whom the first Romanovs were obsessed. ${ }^{8}$ It could also emerge in the form of accusations of imposture toward the reigning autocrat (e.g. Peter I, Catherine II, Alexander I, Nicholas I). While elites were interested in a new social contract with the monarchy, the vast majority of the population was interested in the "natural", "true" king, which was offered to them in the form of the first impostor and the impostors succeeding him.

The presence of the impostor did not allow to "calm down" the autocrat's "religious" charisma: while it cast doubt on the right to the throne of a particular autocrat, it also supported the idea of autocracy itself. As a result, autocrats would be constantly suspected of being impostors, and the serfs would constantly expect a new impostor to arise and proclaim himself the true king. The crisis of differences, the loss of the divinely selected identity and the splitting up of the figure of the king, resonated with the same crisis permeating the body of a slave, whose serfdom in principle deprives him of any personal identity. A slave is someone who is deprived of the right to self-determination; his identity depends entirely on the play of external forces, on the desire of the other. Thus, the overwhelming majority of the population of the kingdom of Muscovy, and then of the Russian Empire, was legally removed from the sense-distinguishing order and immersed in the chaos of non-differentiation. It was this that Pushkin referred to as the "senselessness" of the Russian rebellion (bunt in Russian), which is nothing but the reverse side of the dulling and depersonalizing effects of serfdom.

The final enslavement of the peasants was the work of the new "Slave-Tsars"; Godunov and the Romanovs, whose symbolic legitimacy was defective, leaving them constantly balancing on the brink of the normative order of sameness and differences. This made the expectation of the self-proclaimed "Tsar-God" the only hope for peasants to regain a lost self-identity and, thus, the possibility of self-determination. In the course of this history, autocrats increasingly came to rely on state institutions of violence and bureaucracy and increasingly less on the divine nature of royal power. The resource of imposture would be the masses' hopes for liberation from slavery, as well as the willingness to appeal repeatedly to the old ideas about the sacred symbolism of autocratic power that was manifested in "royal marks" believed to be visible on the bodies of the impostors themselves. ${ }^{9}$ The reasons for such "multistructurality" in types of authority, which competed with one another, but coexisted simultaneously, can be seen in the reproduction of the form of ownership of people which was contemporary

8 Compare to the brutal persecution for the "tsar game" (igra $v$ tsarya), widespread in 17thcentury Muscovy, during which the participants "dressed in tsar's clothes and reproduced appropriate ceremonies" (Uspenskij 1994c: 82-84).

9 On the "tsar signs" as on the most meaningful arguments that proved the verity of imposter pretension for power, see Smirnov 2004: 222-223; Uspenskij 1994c: 81-82. 
to traditional legitimacy, something that, paradoxically, more closely corresponded to the impostors than to the Russian autocrats of the 17th to the 19th centuries. In the end, starting from the Time of Troubles and continuing throughout most of the new imperial period of Russian history, the autocrat and the impostor would go hand in hand, right up until the abolition of serfdom finally ended their common journey.

\section{References}

Bloch, Marc 1998[1924]. Les Rois thaumaturges. Étude sur le caractère surnaturel attribué à la puissance royale particulièrement en France et en Angleterre. Paris: Gallimard.

Chistov, Kirill 2003[1967]. Russkaya narodnaya utopiya (genezis i funktsii sotsial'no-utopicheskih legend). St.Petersburg: Dmitrij Bulanin. [Чистов, К. В. Русская народная утопия (генезис и функиии социально-утопических легенд). Санкт-Петербург: Дмитрий Буланин.]

Frazer, James G. 1994[1890]. The Golden Bough. (Abridged ed.; Fraser, Robert, ed.) Oxford: Oxford University Press.

Girard, René 2005[1972]. Violence and the Sacred. (Gregory, Patrick, trans.) London: Continuum.

Girard, René 1963. Dostoïevski, du double à l'unité. Paris: Plon.

Hobbes, Thomas 1965[1651]. Leviathan or Matter, Form and Power of a Commonwealth Ecclesiastical and Civil. (Reprinted ed.) Oxford: Clarendon Press.

Kalinin, Il'ya 2009. Tartusko-moskovskaya semioticheskaya shkola: semioticheskaya model' kul'tury / kul'turnaya model' semiotiki. Novoe literaturnoe obozrenie 98: 27-56. [Калинин, Илья. Тартуско-московская семиотическая школа: семиотическая модель культуры / культурная модель семиотики. Новое литературное обозрение 98: 27-56.]

Kantorowicz, Ernst 1994[1957]. The King's Two Bodies: A Study in Medieval Political Theology. Princeton: Princeton University Press

Klyuchevskij, Vasilij 1988. Kurs russkoj istorii. Parts 2-3. In: Sochineniya v 9 t. Vol. 3. Moscow: Mysl'. [Ключевский, В. О. 1988. Курс русской истории. Часть II и III. In: Сочинения: $B$ 9 m. Т. ІІІ. Москва: Мысль.]

- 1989. Istoriografiya. In: Sochineniya v 9 t. Vol. 7: Spetsial'nye kursy. Moscow: Mysl'. [Ключевский, В. О. 1989. Историография. In: Сочинения: В 9 m. T. VII: Специальные курсы. Москва: Мысль.]

Kojève, Alexandre 1980[1947]. Introduction to the Reading of Hegel: Lectures on the Phenomenology of Spirit. (Bloom, Allan, ed.) Ithaca: Cornell University Press.

- 2014[1942]. The Notion of Authority. London: Verso.

Margeret, Jacques 1986. Sostoyanie Rossijskoj imperii i velikogo knyazhestva Moskovii. In: Rossiya XV-XVII vv. glazami inostrantsev. Leningrad: Lenizdat, 225-287. [Маржарет, Ж. 1986. Состояние Российской империи и великого княжества Московии. In: Россия XV-XVII вв. глазами иностраниев. Ленинград: Лениздат.]

Massa, Isaac 1937. Kratkoe izvestie o Moskovii v nachale XVII v. Moscow: Sotsekgiz. [Macca, И. Краткое известие о Московии в начале XVII в. Москва: Соцэкгиз.]

Panchenko, Aleksandr 1996. Russkaya kul'tura v kanun Petrovskih reform. In: Iz istorii russkoj kul'tury. Vol. 3. (XVII - nachalo XVIII veka). Moscow: Shkola "Yazyki russkoj kul'tury”, 11264. [Панченко, А. М., Русская культура в канун Петровских реформ. In: Из истории 
русской культуры. T. III (XVII - начало XVIII века). Москва: Школа «Языки русской культуры», 11-264.]

Russkaya istoricheskaya biblioteka, izdavaemaya Arheolograficheskoyu komisseyu. Vol. 13. 1891. St. Petersburg. [Русская историческая библиотека, издаваемая Археографическою комиссиею. Т. ХІІІ. 1891. Санкт-Петербург.]

Schmitt Carl 2005[1922]. Political Theology, Four Chapters on the Concept of Sovereignty. (Schwab, Georg, trans.) Chicago: Chicago University Press.

Skrynnikov, Ruslan 1981. Rossiya nakanune "smutnogo vremeni". Moscow: Mysl'. [Скрынников, Р. Г. 1981. Россия накануне «смутного времени». Москва: Мысль.]

- 1988. Rossiya v nachale XVII v.: «Smuta». Moscow: Mysl'. [Скрынников, Р. Г. Россия в начале XVII в. «Смута». Москва: Мысль.]

Smirnov, Igor 2004. Sotsiosofiya revolyutsii. St. Petersburg: Aletejya. [Смирнов, И. П. Социософия револющии. Санкт-Петербург: Алетейя.]

Uspenskij, Boris 1994a[1976]. Historia sub specie semiotica. In: Uspenskij, Boris, Izbrannye trudy. Vol. 1. Semiotika istorii, semiotika kul'tury. Moscow: Gnozis, 50-60. [Успенский, Б. А. Historia sub specie semiotica. In: Успенский, Б. А., Избранные труды. Т. I: Семиотика истории. Семиотика культуры. Москва: Гнозис, 50-60.]

- 1994b[1989]. Istoriya i semiotika. In: Uspenskij, Boris, Izbrannye trudy. Vol. 1. Semiotika istorii, semiotika kul'tury. Moscow: Gnozis, 9-49. [История и семиотика. In: Успенский, Б. А., Избранные трудь. Т. І: Семиотика истории. Семиотика культуры. Москва: Гнозис, 9-49.]

- 1994c[1982]. Tsar' i samozvanets: samozvanchestvo v Rossii kak kul'turno-istoricheskij fenomen. In: Uspenskij, Boris, Izbrannye trudy. Vol. 1. Semiotika istorii, semiotika kul'tury. Moscow: Gnozis, 75-109. [Царь и самозванец: самозванчество в России как культурноисторический феномен. In: Успенский, Б. А., Избранные труды. Т. I: Семиотика истории. Семиотика культуры. Москва: Гнозис, 75-109.]

- 1994d[1987]. Tsar' i Bog. In: Uspenskij, Boris, Izbrannye trudy. Vol. 1. Semiotika istorii, semiotika kul'tury. Moscow: Gnozis, 110-192. [Царь и Бог. In: Успенский, Б. А., Избранные труды. Т. І: Семиотика истории. Семиотика культуры. Москва: Гнозис, 110-192.]

- 1994e[1985]. Antipovedenie v kul'ture drevnej Rusi. In: Uspenskij, Boris, Izbrannye trudy. Vol. 1. Semiotika istorii, semiotika kul'tury. Moscow: Gnozis, 320-332. [Антиповедение в культуре древней Руси. In: Успенский, Б. А., Избранные труды. Т. I: Семиотика истории. Семиотика культуры. Москва: Гнозис, 320-332.]

- 1998. Tsar' i patriarh: Harizma vlasti v Rossii (vizantijskaya model' i ee russkoe pereosmyslenie). Moscow: Yazyki russkoj kul'tury. [Успенский, Б. А. Царь и патриарх. Харизма власти в России (византийская модель и ее русское переосмысление). Москва: Языки русской культуры.]

Weber, Max 1999[1919]. Politik als Beruf. In: Weber, Max, Gesammelte Politische Schriften (Ausgewählte Schriften). Potsdamer Internet-Ausgabe, 396-450.

Yampol'skij, Mihail 2004. Fiziologiya simvolicheskogo. Book I. Vozvrashchenie Leviafana: Politicheskaya teologiya, reprezentatsiya vlasti i konets Starogo rezhima. Moscow: Novoe literaturnoe obozrenie. [Ямпольский, М. Физиология символического. Книга 1. Возвращение Левиафана: Политическая теология, репрезентация власти и конеи Старого режима. Москва: Новое литературное обозрение.] 


\section{Фигура самозванца в русской политической культуре: между сакрализацией и мимесисом}

Опираясь на материал Смутного времени, статья исследует феномен самозванчества как один из символов, характерных для русской политической истории с XVII по середину XIX века. Период «самозванческой эпидемии» совпадает по времени с существованием в России крепостного права, а сама фигура самозванца может быть описана как социальная реакция на такую форму власти, которая основывается на абсолютной личной зависимости. Целью статьи является дальнейшее развитие тезиса Бориса Успенского, который обнаружил в сакрализации царской власти фундаментальную причину возникновения самозванчества. Концепция миметического желания Рене Жирара служит в качестве теоретической перспективы, актуальной для развития этого тезиса.

\section{Trooninõudleja kuju Vene poliitilises kultuuris: sakraliseerimise ja matkimise vahel}

Lähtudes nn "Segaduste aega" puudutavatest materjalidest vaadeldakse artiklis isehakanud trooninõudluse (samozvanchestvo) nähtust kui üht Vene poliitilise ajaloo sümbolit 17. sajandi algusest kuni 19. sajandi keskpaigani. “Trooninõudlusepideemia” kestvus langeb ajaliselt täpselt kokku pärisorjuse omaga ning trooninõudlemist ennast võib kirjeldada kui ühiskondlikku reaktsiooni võimuvormile, mis põhines täielikult isiklikul sõltuvusel. Artikli peamine eesmärk seisneb katses arendada edasi Boriss Uspenski argumenti, mis paljastab tsaarivõimu sakraliseerimises keskaegsel Venemaal trooninõudlemise põhiprintsiibi. Selle arengu teoreetiliseks perspektiiviks sobib René Girard'i mimeetilise iha mõiste. 